\title{
Analisis Preferensi Konsumen terhadap Produk Gula Aren Di Kecamatan Awayan Kabupaten Balangan
}

\section{(Analysis Of Consumer Preferences On Aren Sugar Products In Awayan District Balangan Regency)}

\author{
Yudhi Harianto $^{(1)}$ \& Nurul Wahdah ${ }^{(2)}$ \\ Program Studi Agribisnis, Sekolah Tinggi Ilmu Pertanian Amuntai \\ 1)Yudhi_harianto015@yahoo.co.id \\ ${ }^{2)}$ nurulwahdah139@gmail.com
}

\begin{abstract}
ABSTRAK
Penelitian ini bertujuan untuk mengkaji atribut gula aren yang menjadi preferensi atau kesukaan konsumen dalam membuat keputusan pembelian gula aren di pasar tradisional yang ada di Kecamatan Awayan Kabupaten Balangan. Penelitian ini dilakukan di pasar tradisional yang ada di Kecamatan Awayan Kabupaten Balangan yaitu Pasar Awayan dan Pasar Bihara. Metode dasar penelitian yang digunakan adalah metode deskriptif kualitatif dan metode pengumpulan data menggunakan metode wawancara. Pengumpulan data dilakukan pada bulan Mei sampai Agustus 2017. Penentuan sampel penelitian menggunakan metode simple random sampling secara undian dengan jumlah sampel 50 orang. Jenis data yang digunakan adalah data primer dan data sekunder. Alat analisis yang digunakan adalah analisis Chi-Square. Hasil analisis Chi-Square menunjukkan bahwa seluruh variabel gula aren berbeda nyata pada taraf kepercayaan $95 \%$. Artinya preferensi konsumen terhadap gula aren di pasar tradisional di Kecamatan Awayan Kabupaten Balangan tidak sama atau terdapat perbedaan preferensi konsumen terhadap gula aren dan semua atribut termasuk dalam preferensi konsumen. Gula aren yang menjadi preferensi konsumen di pasar tradisional Kecamatan Awayan Kabupaten Balangan adalah gula aren yang memiliki warna cokelat, rasa manis, ukuran sedang, kemasan plastik dan harga berkisar antara Rp. 16.000,00-Rp. 18.000,00 per kg.
\end{abstract}

Kata Kunci : Gula aren, preferensi, konsumen, analisis Chi-Square.

\section{ABSTRACT}

This study aims to examine the attributes of palm sugar which is the preference or preference of consumers in making decisions to purchase palm sugar in traditional markets in the District of Awayan, Balangan Regency. This research was conducted in traditional markets in Awayan District, Balangan Regency, namely Awayan Market and Bihara Market. The basic method of research used is a qualitative descriptive method and the method of data collection using the interview method. Data collection was carried out from May to August 2017. Determination of the study sample using lottery simple random sampling method with a sample size of 50 people. The types of data used are primary data and secondary data. The analytical tool used is Chi-Square analysis. The results of the Chi-Square analysis showed that all variables of palm sugar were significantly different at the $95 \%$ confidence level. This means that consumer preference for palm sugar in traditional markets in Awayan District, Balangan Regency is not the same or there are differences in consumer preferences for palm sugar and all attributes included in consumer preferences. Palm sugar which is the preference of consumers in the traditional market of Awayan Subdistrict, Balangan Regency is palm sugar which has a brown color, sweet taste, medium size, plastic packaging and prices range from Rp. 16,000.00 - Rp. 18,000.00 per kg.

Keywords: Palm sugar, preferences, consumers, Chi-Square analysis.

\section{PENDAHULUAN}

Indonesia dengan jumlah penduduk yang besar merupakan pasar yang potensial (Suwarto et. al., 2014). Seperti halnya dengan industri gula. Jumlah penduduk yang besar tersebut merupakan potensi pasar yang baik bagi komoditas gula, di mana permintaan gula terus meningkat tiap tahunnya.

Salah satu jenis industri pemanis makanan yang berkembang di Indonesia adalah industri gula merah atau gula aren. Produk gula aren memiliki pasar yang sangat 
luas, tidak hanya ada di dalam negeri tetapi juga di luar negeri seperti Arab Saudi, Amerika Serikat, Australia, Selandia Baru, Jepang dan Kanada. Gula aren terdiri dari gula aren cetak, pasir dan semut. Gula aren banyak dimanfaatkan untuk berbagai macam keperluan, seperti untuk pembuatan kue, kecap dan produk pangan lainnya. Gula aren sering juga digunakan di dalam ramuan obat tradisional dan diyakini dapat menjadi obat demam dan sakit perut. Gula aren mengandung glukosa cukup tinggi yang dapat membersihkan ginjal sehingga mampu mencegah penyakit ginjal. Kekhasan gula aren dari segi kimia yaitu mengandung sukrosa kurang lebih $84 \%$ dibandingkan dengan gula tebu dan gula bit yang masingmasing hanya $20 \%$ dan $17 \%$ sehingga gula aren mampu menyediakan energi yang lebih tinggi dari gula tebu dan gula bit (Lempang, 2012).

Pengembangan usaha gula aren di Kalimantan Selatan khususnya Kabupaten Balangan memiliki berpotensi yang besar, karena banyaknya masyarakat lokal dan non lokal yang menggemari produk tersebut. Produksi rata-rata gula aren di Kecamatan Awayan mencapai 1,8 ton/tahun untuk tiap produsen. Harga jual gula aren di Kecamatan Awayan umumnya adalah Rp. 16.000,-/kg dan bisa mengalami kenaikan harga maksimum sampai dengan Rp. 20.000,-/kg. Kesadaran masyarakat akan pentingnya kesehatan membuat mereka mulai selektif dalam memilih dan mengkonsumsi makanan. Mengkonsumsi makanan yang manis merupakan salah satu kebiasaan masyarakat, sehingga tidak bisa terlepas dari konsumsi gula. Gula aren memiliki kandungan kalori yang lebih rendah dibanding gula tebu dan bit, sehingga lebih baik dikonsumsi untuk memenuhi kebutuhan kalori yang seimbang di mana sumber kalori yang lebih tinggi didapat dari konsumsi makanan yang berkarbohidrat tinggi seperti padi-padian. Hal ini merupakan salah satu penyebab tingginya permintaan konsumen terhadap gula aren. Upaya produsen dalam memenuhi kebutuhan pasar akan produk gula aren menjadikan mereka perlu mengetahui selera konsumen, agar gula aren yang dipasarkan mendapat respon yang baik dari konsumen.
Produsen maupun pemasar harus mampu menyediakan gula aren dengan atribut fisik yang sesuai dengan kebutuhan dan keinginan konsumen.

Konsumen memutuskan membeli suatu produk dapat dilihat dari segi situasi ekonomi, kepribadian dan konsep diri, motivasi, persepsi, pembelajaran, kepercayaan dan sikap. Ketika konsumen akan bertindak sesuai dengan keinginannya, maka keputusan konsumen terhadap pembelian suatu produk akan semakin kuat (Nitisusastro, 2012). Tujuan penelitian ini yaitu ingin mengetahui bagaimana preferensi konsumen terhadap produk gula aren di Kecamatan Awayan Kabupaten Balangan dalam pengambilan keputusan pembelian.

\section{METODE PENELITIAN}

\section{Lokasi dan Waktu Penelitian}

Penelitian ini dilaksanakan di Kecamatan Awayan Kabupaten Balangan.Penelitian dilakukan mulai bulan Mei sampai dengan selesai.

\section{Jenis dan Sumber Data}

Jenis data yang digunakan dalam penelitian ini terdiri dari data sekunder dan data primer. Data sekunder merupakan data yang diperoleh dari instansi-instansi, perpustakaan, maupun dari pihak lainnya. Sedangkan data primer diperoleh secara langsung dari responden atau objek yang diteliti dengan cara wawancara menggunakan kuisioner atau angket.

\section{Metode Pengumpulan Data}

Metode pengumpulan data pada penelitian ini dilakukan dengan metode wawancara secara langsung kepada konsumen gula aren atau responden dengan menggunakan kuesioner. Populasi sebanyak 100 orang, agar data representatif maka pada penelitian ini digunakan teknik pengambilan sampel dengan menggunakan metode probability sampling dengan teknik simple random sampling, yaitu cara pengambilan sampel dari anggota populasi secara acak tanpa memperhatikan strata (tingkatan) dalam anggota populasi tersebut. Jumlah sampel dapat ditentukan dengan 
menggunakan rumus Slovin dengan nilai kritis $10 \%$ yaitu sebagai berikut :

$\mathrm{n}=\frac{\mathrm{N}}{1+\mathrm{Ne}^{2}}$

Keterangan :

n : Jumlah sampel

$\mathrm{N}$ : Jumlah populasi

e : Nilai kritis

$\mathrm{n}=\frac{100}{1+100(0,1)^{2}}$

$\mathrm{n}=\frac{100}{1+100(0,01)}$

$\mathrm{n}=\frac{100}{2}$

$\mathrm{n}=50$ responden

Berdasarkan hasil perhitungan jumlah sampel pada ke dua tempat tersebut diperoleh sampel sebanyak 25 orang responden untuk Pasar Awayan dan 25 orang responden untuk Pasar Bihara. Penentuan responden dari kedua tempat tersebut dilakukan secara random atau acak dengan cara undian.

\section{Analisis Data}

Analisis data yang digunakan pada penelitian ini adalah analisis Chi-Square goodness-of-fit. Analisis Chi-Square digunakan untuk mengetahui atribut gula aren yang menjadi preferensi konsumen yang ada di Kecamatan Awayan Kabupaten Balangan yang dapat dilakukan dengan menggunakan rumus berikut.

$x^{2}=\sum_{i=1}^{k}\left[\frac{\left(f_{o-} f_{e}\right)^{2}}{f_{e}}\right]$

Keterangan :

$x^{2}=$ Chi-Square

$\mathrm{f}_{\mathrm{o}} \quad=$ Frekuensi hasil pengamatan pada penelitian

$\mathrm{f}_{\mathrm{e}} \quad=$ Frekuensi yang diharapkan pada penelitian

i...k = Kategori atribut dalam variabel gula aren

Hipotesis yang digunakan adalah :

$\mathrm{H}_{\mathrm{o}} \quad$ : Tidak terdapat perbedaan preferensi konsumen terhadap masing-masing atribut yang ada

pada gula aren.

$\mathrm{H}_{\mathrm{a}}$ : Terdapat perbedaan preferensi konsumen terhadap masing-masing atribut yang ada pada gula aren.

Pengujian pada tingkat kepercayaan 95\% dengan kriteria pengujian :

1. Jika $x^{2}$ hitung $>x^{2}$ tabel, maka $\mathrm{H}_{\mathrm{o}}$ ditolak dan $\mathrm{H}_{\mathrm{a}}$ diterima.

2. Jika $x^{2}$ hitung $\leq x^{2}$ tabel, maka $\mathrm{H}_{\mathrm{o}}$ diterima dan $\mathrm{H}_{\mathrm{a}}$ ditolak.

\section{HASIL DAN PEMBAHASAN}

\section{Karakteristik Responden}

\section{Hasil}

1) Jenis Kelamin

Tabel 1. Karakteristik responden konsumen gula aren menurut jenis kelamin

\begin{tabular}{cccc}
\hline No. & & Jenis Kelamin & Jumlah Responden (Orang) \\
\hline 1. & Perempuan & & 48 \\
2. & Laki-Laki & & 2 \\
\hline & & Jumlah & 50 \\
\hline
\end{tabular}

Sumber : Pengolahan data primer (2017).

Berdasarkan tabel tersebut dapat diketahui bahwa jumlah responden semua berjenis kelamin perempuan.

2) Usia

Tabel 2. Karakteristik responden konsumen gula aren menurut usia

No. Kelompok Umur (Tahun) Jumlah Responden (Orang)




\begin{tabular}{lrc}
\hline 1. & $20-25$ & 8 \\
2. & $26-30$ & 7 \\
3. & $31-36$ & 12 \\
4. & $37-41$ & 7 \\
5. & $42-47$ & 8 \\
6. & $48-53$ & 4 \\
7. & $54-59$ & 2 \\
8. & $60-65$ & 2 \\
\hline
\end{tabular}

Sumber : Pengolahan data primer (2017).

Tabel tersebut menunjukkan bahwa responden konsumen gula aren terbanyak adalah pada usia 31-36 tahun yaitu sebanyak 12 orang.

3) Tingkat Pendidikan

Tabel 3. Karakteristik Responden Konsumen Gula Aren menurut Tingkat Pendidikan

\begin{tabular}{|c|c|c|}
\hline No. & Tingkat Pendidikan & Jumlah Responden (Orang) \\
\hline 1. & Tidak Tamat SD & 8 \\
\hline 2. & SD & 10 \\
\hline 3 . & SMP & 17 \\
\hline 4. & SMA & 14 \\
\hline 5. & S1 & 1 \\
\hline & Jumlah & 50 \\
\hline
\end{tabular}

Sumber : Pengolahan data primer (2017).

Tabel tersebut menunjukkan bahwa tingkat pendidikan terbanyak responden

konsumen gula aren adalah SMP yaitu 17 responden.

4) Jenis Pekerjaan

Tabel 4. Karakteristik Responden Konsumen Gula Aren menurut Jenis Pekerjaan

\begin{tabular}{clc}
\hline No. & \multicolumn{1}{c}{ Jenis Pekerjaan } & Jumlah Responden (Orang) \\
\hline 1. & Wiraswasta & 16 \\
2. & Petani & 12 \\
3. & Pedagang & 1 \\
4. & Ibu Rumah Tangga & 19 \\
5. & Mahasiswa & 2 \\
\hline \multicolumn{2}{r}{ Jumlah } & 50 \\
\hline
\end{tabular}

Sumber : Pengolahan data primer (2017).

Tabel tersebut menunjukkan bahwa sebagian besar konsumen yang membeli gula aren adalah ibu rumah tangga yaitu 19 orang.

5) Penghasilan Rumah Tangga

Tabel 5. Karakteristik responden gula aren menurut penghasilan rumah tangga 


\begin{tabular}{ccc}
\hline No. & Pendapatan $(\mathrm{Rp})$ & Jumlah Responden (Orang) \\
\hline 1. & $500.000-700.000$ & 12 \\
2. & $800.000-1.000 .000$ & 13 \\
3. & $1.100 .000-1.300 .000$ & 4 \\
4. & $1.400 .000-1.600 .000$ & 9 \\
5. & $1.700 .000-1.900 .000$ & 1 \\
6. & $2.000 .000-2.200 .000$ & 7 \\
7. & $2.300 .000-2.500 .000$ & 5 \\
\hline
\end{tabular}

Sumber : Pengolahan data primer (2017).

Tabel tersebut menunjukkan bahwa penghasilan sebagian besar responden yang membeli gula aren adalah sebesar Rp. 800.000 sampai Rp. 1.000.000,- per bulan dengan jumlah 13 orang.

6) Jumlah Anggota Keluarga

Tabel 6. Karakteristik responden gula aren menurut jumlah anggota keluarga

\begin{tabular}{ccc}
\hline No. & Jumlah Anggota Keluarga (Orang) & Jumlah Responden (Orang) \\
\hline 1. & 1 & 1 \\
2. & 2 & 9 \\
3. & 3 & 15 \\
4. & 4 & 17 \\
5. & 5 & 3 \\
6. & 6 & 5 \\
\hline & Jumlah & 50 \\
\hline
\end{tabular}

Sumber : Pengolahan data primer (2017).

Tabel tersebut menjelaskan bahwa

mempunyai jumlah anggota keluarga 4 sebagian besar konsumen gula aren orang yaitu 17 orang responden.

\section{Perilaku Beli Responden}

1) Tempat dan Alasan Pembelian

Tabel 7. Tempat pembelian gula aren oleh responden di Kecamatan Awayan Kabupaten Balangan

\begin{tabular}{cccc}
\hline No. & Nama Pasar & Jumlah Penjual Gula Aren & Jumlah Responden (Orang) \\
\hline 1. & Pasar Awayan & 6 & 25 \\
2. & Pasar Bihara & 4 & 25 \\
\hline & Jumlah & 10 & 50 \\
\hline
\end{tabular}

Sumber : Pengolahan data primer (2017).

Tabel 8. Alasan pembelian gula aren oleh responden di Kecamatan Awayan Kabupaten Balangan

\begin{tabular}{clc}
\hline No. & \multicolumn{1}{c}{ Alasan Pembelian } & Jumlah (Orang) \\
\hline 1. & Dekat Rumah & 18 \\
2. & Kualitas Gula Bagus & 8 \\
3. & Harga Lebih Murah & 7
\end{tabular}


4. Gula Asli

5. Stok Tersedia

\section{2}

6. Berlangganan

7. Kebutuhan

8. Penjualnya Ramah

9. Rasa Gula Enak dan Harum

Sumber : Pengolahan data primer (2017).

\section{2) Frekuensi Pembelian}

Tabel 9. Frekuensi pembelian gula aren oleh responden di Kecamatan Awayan Kabupaten Balangan

\begin{tabular}{clc}
\hline No. & \multicolumn{1}{c}{ Frekuensi Pembelian } & Jumlah Responden (Orang) \\
\hline 1. & Setiap Hari & 0 \\
2. & Satu Kali Seminggu & 21 \\
3. & Dua Kali Seminggu & 7 \\
4. & TidakTentu & 22 \\
\hline & $\quad$ Jumlah & 50 \\
\hline
\end{tabular}

Sumber : Pengolahan data primer (2017).

Tabel tersebut menunjukkan terhadap gula aren lebih dominan pada bahwa frekuensi pembelian konsumen waktu yang tidak tentu.

3) Jumlah Pembelian

Tabel 10. Jumlah Pembelian Gula Aren oleh Responden di Kecamatan Awayan Kabupaten Balangan

\begin{tabular}{ccc}
\hline No. & Jumlah Pembelian $(\mathrm{Kg})$ & Jumlah Responden (Orang) \\
\hline 1. & $<1 \mathrm{Kg}$ & 20 \\
2. & $1-2 \mathrm{Kg}$ & 27 \\
3. & $>2 \mathrm{Kg}$ & 3 \\
\hline & Jumlah & 50 \\
\hline
\end{tabular}

Sumber : Pengolahan data primer (2017).

Tabel tersebut menunjukkan

gula aren dengan jumlah $1-2 \mathrm{~kg}$ dengan bahwa sebagian besar konsumen membeli jumlah responden 27 orang.

4) Tujuan Pembelian Gula Aren

Tabel 11. Tujuan pembelian gula aren oleh responden di Kecamatan Awayan Kabupaten Balangan

\begin{tabular}{clc}
\hline No. & \multicolumn{1}{c}{ Tujuan Pembelian } & Jumlah Responden (Orang) \\
\hline 1. & Dikonsumsi sendiri & 49 \\
2. & Oleh-oleh & 1 \\
\hline & & Jumlah
\end{tabular}

Sumber : Pengolahan data primer (2017). 
Tabel tersebut menunjukkan bahwa sebagian besar konsumen membeli gula aren di Pasar Awayan dan Pasar
Bihara adalah untuk dikonsumsi sendiri yaitu sebanyak 49 responden.

\section{Preferensi Responden terhadap Atribut Gula Aren}

1) Preferensi Responden terhadap Atribut Warna Gula Aren

Tabel 12. Hasil analisis chi-square pada atribut warna gula aren

\begin{tabular}{|c|c|c|c|c|c|}
\hline Jenis Warna & fo & $\mathrm{Fe}$ & fo-fe & $(\text { fo-fe })^{2}$ & $(\mathrm{fo}-\mathrm{fe})^{2} / \mathrm{fe}$ \\
\hline Cokelat Kehitaman & 7 & 16,67 & $-9,67$ & 93,509 & 5,609 \\
\hline Cokelat & 28 & 16,67 & 11,33 & 128,369 & 7,701 \\
\hline Kuning & 15 & 16,67 & $-1,67$ & 2,789 & 0,167 \\
\hline Jumlah & 50 & 50 & 0 & 224,667 & 13,477 \\
\hline
\end{tabular}

Sumber : Pengolahan data primer (2017).

Jumlah kategori yang diobservasi ada 3, maka $\mathrm{db}=2$ yaitu nilai sebesar 5,990.

Berdasarkan perhitungan diperoleh hasil

bahwa nilai $x^{2}$ hitung $(13,477)>x^{2}$ tabel $(5,990)$. Artinya Ho ditolak dan $\mathrm{Ha}$ diterima.

2) Preferensi Responden terhadap Atribut Warna Rasa Aren

Tabel 13. Hasil analisis chi-square pada atribut rasa gula aren

\begin{tabular}{lccccc}
\hline \multicolumn{1}{c}{ Jenis Rasa } & fo & fe & fo-fe & (fo-fe) $)^{2}$ & (fo-fe $)^{2} / \mathrm{fe}$ \\
\hline Manis Sekali & 18 & 16,67 & 1,33 & 1,769 & 0,106 \\
Manis & 29 & 16,67 & 12,33 & 152,029 & 9,119 \\
Manis Sedikit Asam & 3 & 16,67 & $-13,67$ & 186,869 & 11,209 \\
\hline \multicolumn{1}{c}{ Jumlah } & 50 & 50 & 0 & 340,667 & 20,434 \\
\hline
\end{tabular}

Sumber : Pengolahan data primer (2017).

Jumlah kategori yang diobservasi ada 3, maka $\mathrm{db}=2$ yaitu nilai sebesar 5,990.

Berdasarkan perhitungan diperoleh hasil

bahwa nilai $x^{2}$ hitung $(20,434)>x^{2}$ tabel $(5,990)$. Artinya Ho ditolak dan $\mathrm{Ha}$ diterima

3) Preferensi Responden terhadap Atribut Ukuran Gula Aren

Tabel 14. Hasil analisis chi-square pada atribut ukuran gula aren

\begin{tabular}{lccccc}
\hline \multicolumn{1}{c}{ Jenis Ukuran } & fo & fe & fo-fe & ${\text { (fo-fe })^{2}}$ & (fo-fe) $^{2} / \mathrm{fe}$ \\
\hline Besar (1 biji/kg) & 20 & 16,67 & 3,33 & 11,089 & 0,665 \\
Sedang (1-2 biji/kg) & 25 & 16,67 & 8,33 & 69,389 & 4,163 \\
Kecil (> 2 biji/kg) & 5 & 16,67 & $-11,67$ & 136,189 & 8,169 \\
\hline \multicolumn{1}{c}{ Jumlah } & 50 & 50 & 0 & 216,667 & 12,997 \\
\hline
\end{tabular}

Sumber : Pengolahan data primer (2017).

4) Preferensi Responden terhadap Atribut Warna Kemasan Aren 
Tabel 15. Hasil analisis chi-square pada atribut kemasan gula aren

\begin{tabular}{lcccccc}
\hline & Jenis Kemasan & fo & fe & fo-fe & ${\text { (fo-fe })^{2}}$ & (fo-fe) $^{2} / \mathrm{fe}$ \\
\hline Daun & 17 & 25 & -8 & 64 & 2,56 \\
Plastik & 33 & 25 & 8 & 64 & 2,56 \\
\hline \multicolumn{2}{c}{ Jumlah } & 50 & 50 & 0 & 128 & 5,12 \\
\hline
\end{tabular}

Sumber : Pengolahan data primer (2017).

Jumlah kategori yang diobservasi ada 2, maka $\mathrm{db}=1$ yaitu nilai sebesar 3,840 . Berdasarkan perhitungan diperoleh hasil

bahwa nilai $x^{2}$ hitung $(5,12)>x^{2}$ tabel $(3,840)$. Artinya Ho ditolak dan $\mathrm{Ha}$ diterima.

5) Preferensi Responden terhadap Atribut Warna Harga Aren

Tabel 16. Hasil analisis chi-square pada atribut harga gula aren

\begin{tabular}{|c|c|c|c|c|c|}
\hline Jenis Harga (Rp) & fo & fe & fo-fe & $(\text { fo-fe })^{2}$ & $(\mathrm{fo}-\mathrm{fe})^{2} / \mathrm{fe}$ \\
\hline$<16.000$ & 13 & 16,67 & $-3,67$ & 13,469 & 0,808 \\
\hline $16.000-18.000$ & 29 & 16,67 & 12,33 & 152,029 & 9,119 \\
\hline$>18.000$ & 8 & 16,67 & $-8,67$ & 75,169 & 4,509 \\
\hline Jumlah & 50 & 50 & 0 & 240,667 & 14,436 \\
\hline
\end{tabular}

Sumber : Pengolahan data primer (2017).

Jumlah kategori yang diobservasi ada 3, maka $\mathrm{db}=2$ yaitu nilai sebesar 5,990 . Berdasarkan perhitungan diperoleh hasil bahwa nilai $x^{2}$ hitung $(14,436)>x^{2}$ tabel $(5,990)$. Artinya Ho ditolak dan Ha diterima.
Preferensi konsumen terhadap produk gula aren dapat dilihat dari nilai yang diberikan konsumen pada masing-masing atribut. Penilaian kosumen pada masingmasing atribut dapat dilihat pada tabel berikut

Tabel 17. Preferensi responden terhadap produk gula aren di Kecamatan Awayan Kabupaten Balangan

\begin{tabular}{|c|c|c|}
\hline No. & Atribut Gula Aren & Preferensi Konsumen \\
\hline & Warna & Cokelat \\
\hline 2. & Rasa & Manis \\
\hline 3. & Ukuran & Sedang \\
\hline 4. & Kemasan & Plastik \\
\hline 5. & Harga & Rp. $16.000,00-$ Rp. $18.000,00$ \\
\hline
\end{tabular}

Sumber : Pengolahan data primer (2017).

Tabel di atas menunjukkan hasil bahwa gula aren yang menjadi preferensi konsumen adalah gula aren yang berwarna cokelat, rasa manis, ukuran sedang,

\section{Pembahasan}

Hasil analisis preferensi konsumen terhadap atribut gula aren yang dibeli di Pasar Awayan dan Pasar Bihara di Kecamatan Awayan Kabupaten Balangan dengan berkemasan plastik dengan harga yang tidak terlalu mahal berkisar antara Rp.16.000,00 Rp. $18.000,00$ per kg.

menggunakan analisis Chi-Square menunjukkan nilai $x^{2}$ dari atribut warna sebesar 13,447, atribut rasa sebesar 20,434, atribut ukuran sebesar 12,997, atribut kemasan sebesar 5,12 dan atribut harga sebesar 14,436 . Hasil perhitungan analisis 
Chi-Square dari semua atribut yang diteliti menunjukkan hasil bahwa semua atribut yang diamati dalam penelitian ini menunjukkan nilai $x^{2}$ hitung $>x^{2}$ tabel dengan taraf kepercayaan sebesar $95 \%$ yang berarti bahwa semua atribut gula aren yang diteliti merupakan preferensi atau kesukaan konsumen. Hasil penelitian juga sudah sesuai dengan hipotesis pada penelitian ini yaitu terdapat perbedaan preferensi konsumen dari semua atribut yang diteliti dan gula aren yang menjadi preferensi konsumen dalam membuat keputusan pembelian adalah gula aren yang memiliki warna cokelat, rasa manis, ukuran sedang, berkemasan plastik dengan harga yang tidak terlalu mahal berkisar antara Rp. $16.000,00-\mathrm{Rp}$. $18.000,00$ per $\mathrm{kg}$.

\section{KESIMPULAN}

Berdasarkan hasil penelitian dan analisa yang telah dilakukan dengan menggunakan analisis Chi-Square maka dapat disimpulkan bahwa terdapat perbedaan preferensi konsumen pada semua atribut gula aren yang diteliti di Kecamatan Awayan Kabupaten Balangan. Gula aren yang menjadi preferensi konsumen dalam pengambilan keputusan pembelian adalah gula aren yang berwarna cokelat, rasanya manis, berukuran sedang, kemasan yang digunakan adalah plastik dan harganya tidak terlalu mahal berkisar antara Rp. 16.000,00 Rp. 18.000,00 per kg.

\section{DAFTAR PUSTAKA}

Lempang, M. 2012. Pohon Aren dan Manfaat Produksinya. Info Teknis Eboni. Balai Penelitian Kehutanan Makassar. (http://www.fordamof.org,Diakses tanggal 05 Maret 2017).

Nitisusastro, M. 2012. Perilaku Konsumen dalam Persepektif Kewirausahaan. Alfabeta. Bandung.

Suwarto, Yuke Octavianty dan Silvia Hermawati. 2014. Top 15 Tanaman Perkebunan. Penebar Swadaya. Jakarta. 